\title{
THE INFLUENCE OF DETERGENTS AND TRYPSIN ON THE STIMULATION OF AMYLASE SECRETION BY EITHER PANCREOZYMIN OR SODIUM FLUORIDE IN THE PERFUSED RAT PANCREAS
}

\author{
Patrick Robberecht, Monique Deschodt-Lanckman, Jean Camus \\ and JEAN CHRISTOPHE \\ Department of Biochemistry and Nutrition, University of Brussels \\ Medical School, B-1000 Brussels, Belgium
}

(Receited 25 September 1974; accepted 14 February 1975)

\begin{abstract}
Rat pancreas fragments were perfused for $2 \mathrm{hr}$ with Krebs-Ringer bicarbonate buffer enriched with $10 \mathrm{mM}$ glucose and Trasylol $(500 \mathrm{UIK} / \mathrm{ml})$. Amylase output was estimated at 5 -min intervals on successive samples of the effluent. (2) Pancreozymin at a concentration of $7.10^{-9} \mathrm{M}$ doubled amylase output when introduced after $1 \mathrm{hr}$ of preincubation. Administration of $10 \mathrm{mM}$ NaF promoted a biphasic effect. The initial and transient hypersecretory peak was followed by a second and more prolonged period of hypersecretion. It is assumed that the primary component of the biphasic response was due to hyperosmolarity, and it is tentatively suggested that the secondary response to NaF was the result of variations in the phosphorylation of membrane proteins. (3) Paired tissue fragments were pre-exposed for $30 \mathrm{~min}$ to digitonin, sodium dodecylsulfate, Triton X-100, or bovine trypsin (the proteolytic enzyme in the absence of Trasylol). The basal output of amylase rose with increasing detergent concentrations (from 100 to $500 \mu \mathrm{g} / \mathrm{ml}$ ) but not after trypsin pretreatment. The four agents were equally effective in reducing the sensitivity to pancreozymin. They did not impair the initial osmotic response to $\mathrm{NaF}$, but did curtail the prolonged second $\mathrm{NaF}$ hypersecretory effect. Digitonin and dodecylsulfate were less effective in this respect than either Triton X-100 or trypsin though being equally detrimental to pancreozymin action. (4) These observations suggest that the regulation in vitro of secretion by pancreozymin and $\mathrm{NaF}$ in intact acinar cells of the rat pancreas involves two distinct loci of a membrane-lipoprotein complex.
\end{abstract}

The mode of action of pancreozymin upon the pancreatic acinar cell is a much debated question. Three hypotheses may account for stimulus-secretion coupling: (1) the stimulation of an adenylate cyclase of the plasma membrane; (2) the translocation of calcium and (3) the activation of guanylate cyclase. None of these possibilities have been clearly demonstrated up to the present time. However, since a hormone with a mol. wt of approx 4000 cannot readily penetrate the plasma membrane, the binding of pancreozymin to appropriate plasma membrane receptors must represent an essential part of the transmission of the message.

Unfortunately, it is still difficult to undertake a direct study of pancreozymin binding. The purification of plasma membrane is a delicate operation in the case of a tissue rich in digestive hydrolases. Furthermore, the preparation of radioactive pancreozymin of high specific activity presents difficulties with respect to the lack of free phenol function available for iodination. These considerations warrant an indirect approach to the problem, involving the manipulation of intact cells. We have investigated the influence of 30 -min pretreatment with detergent or trypsin (EC 3.4.4.4) on the time course in vitro of basal amylase output. We have also compared the action of these agents, known to alter membrane function, on the stimulation of secretion by pancreozymin and sodium fluoride when the secretagogues are added at the end of $1 \mathrm{hr}$ of perifusion.

\section{METHODS}

Pancreatic tissue was obtained from batches of four male Wistar strain rats $(175-225 \mathrm{~g})$. The fragments were prepared and the complete experimental set-up organized as described previously [1]. In each experiment, pancreatic fragments from a combined pool were randomly distributed among six $1.8-\mathrm{ml}$ perfusion cells. Each cell received ten fragments weighing approx $300 \mathrm{mg}$ altogether. The fragments were perfused (superfused) at $37^{\circ}$ with constant delivery $(20 \mathrm{ml} / \mathrm{hr})$ of Krebs-Ringer bicarbonate buffer

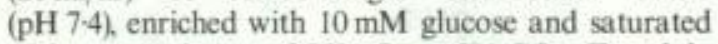
with a gas mixture of $95 \% \mathrm{O}_{2}+5 \% \mathrm{CO}_{2}$. TrasylolBayer (the Kunitz inhibitor of proteolytic enzymes) was also present at a concentration of 500 kallikrein inhibitor units (UIK) $/ \mathrm{ml}$, except as indicated. Fivemin successive samples of the effluent were directed to a fraction collector maintained at $2^{\circ}$. A proportioning pump (Model I, Technicon Instruments Co., Tarrytown, U.S.A.) and three-way stopcocks allowed the smooth switch over to other solutions.

The same experimental protocol was followed in all trials. The first three perfusion cells served as controls and the pancreatic fragments were unexposed 
to detergent or trypsin. In a second set of three cells. the noxious agent was tested at a single concentration: the fragments were exposed for $30 \mathrm{~min}$ to $0-010,0-025$ or $0-050 \%$ concentrations (w/w) of either digitonin, sodium dodecylsulfate, Triton X-100 or bovine trypsin. Normal Krebs-Ringer-glucose medium was perfused during the following $30 \mathrm{~min}$ to eliminate detergent or trypsin. Pancreozymin ( 320 Crick. Harper and Raper units/ml) or $10 \mathrm{mM} \mathrm{NaF}$ was added to the perfusion medium of two of the three cells after the second $30 \mathrm{~min}$. Trasylol was present at all times except for $30 \mathrm{~min}$ in those experiments when bovine trypsin was present. Each experimental curve illustrated in Figs, 1-4 can be directly compared to the corresponding curve in Figs. 5-8 obtained after perfusion of paired fragments.

$\alpha$-Amylase in the perfusion medium and in the tissue was estimated by the saccharogenic method of Noelting and Bernfeld [2] as automated by Vandermeers et al. [3]. One unit of amylase is defined as the amount of enzyme which liberates a reducing power equivalent to $1 \mu$ mole of maltose per min at $25^{\circ}$. Hydrolase secretion was expressed as per cent of total initial content secreted in $5 \mathrm{~min}$, the total amylase content being estimated by adding the amounts secreted to the residual enzyme in the fragments.

Digitonin and $\mathrm{NaF}$ were purchased from Merck (Darmstadt, Germany). Sodium dodecylsulfate (SDS) was obtained from BDH Chemicals Ltd. (Poole, Eng- land); Triton X-100 from Rohm and Haas Co. (Philadelphia, U.S.A.); bovine trypsin ( $2 \times$ crystallized saltfree, lyophilized) from Worthington Biochemical Corp. (Freehold, U.S.A.) and pancreozymin from the GIH Research Unit of the Karolinska Institute (Stockholm, Sweden).

\section{RESULTS}

Control values of amylase secretion. In the absence of any of the four agents under study, the basal output of amylase decreased rapidly during the first $10 \mathrm{~min}$ of perfusion. This period corresponded to the clearing up of cell debris accumulated during the preliminary manipulations of the pancreases and to the washing-out of hydrolases stagnating in ductules. Thereafter, the secretion remained relatively stable, the average output of amylase being approx $0.4 \%$ per 5 min of the initial tissue content.

Effects of pancreozymin with or without preliminary treatment with detergents of trypsin. Figures 1-4 illustrate the effects of increasing concentrations of digitonin, sodium dodecylsulfate, Triton $\mathrm{X}-100$ and bovine trypsin on amylase output. It is clear that this basal output increased under all circumstances except following trypsin treatment or low concentrations of Triton X-100.

The continuous infusion of pancreozymin, added in supra-maximal concentration $\left(7.10^{-9} \mathrm{M},[1]\right)$ after $1 \mathrm{hr}$ of perfusion without any of the four agents,
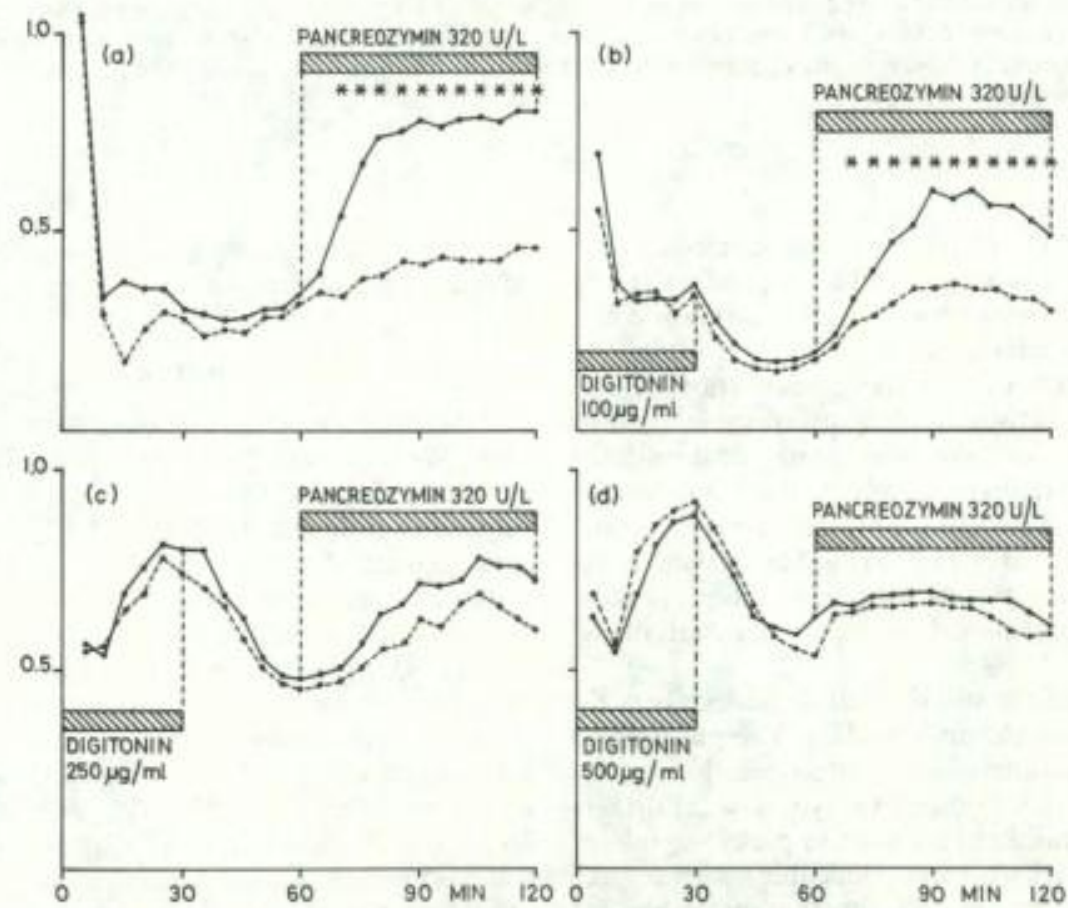

Fig. 1. Effect of digitonin pretreatment on amylase secretion by rat pancreas fragments perifused in the presence (-) and in the absence (- ) of pancreozymin. When added, pancreozymin (320 CHR U/1.) was introduced (E) after $60 \mathrm{~min}$ in a hormone-free medium. (a) shows the control secretion profile obtained with a Krebs-Ringer bicarbonate buffer, enriched with $10 \mathrm{mM}$ glucose and Trasylol $(500 \mathrm{UIK} / \mathrm{ml})$. (b-d) illustrate the effects of digitonin on amylase output from paired fragments. The drug was administered in increasing concentrations $(100,250$, and $500 \mu \mathrm{g} / \mathrm{ml})$ and withdrawn at time 30 min. Each curve is the mean of three experiments. Asterisks show in this and subsequent figures where differences are significant $(\mathrm{P}<0-05)$, when values obtained with the test substance are compared with paired control data. 

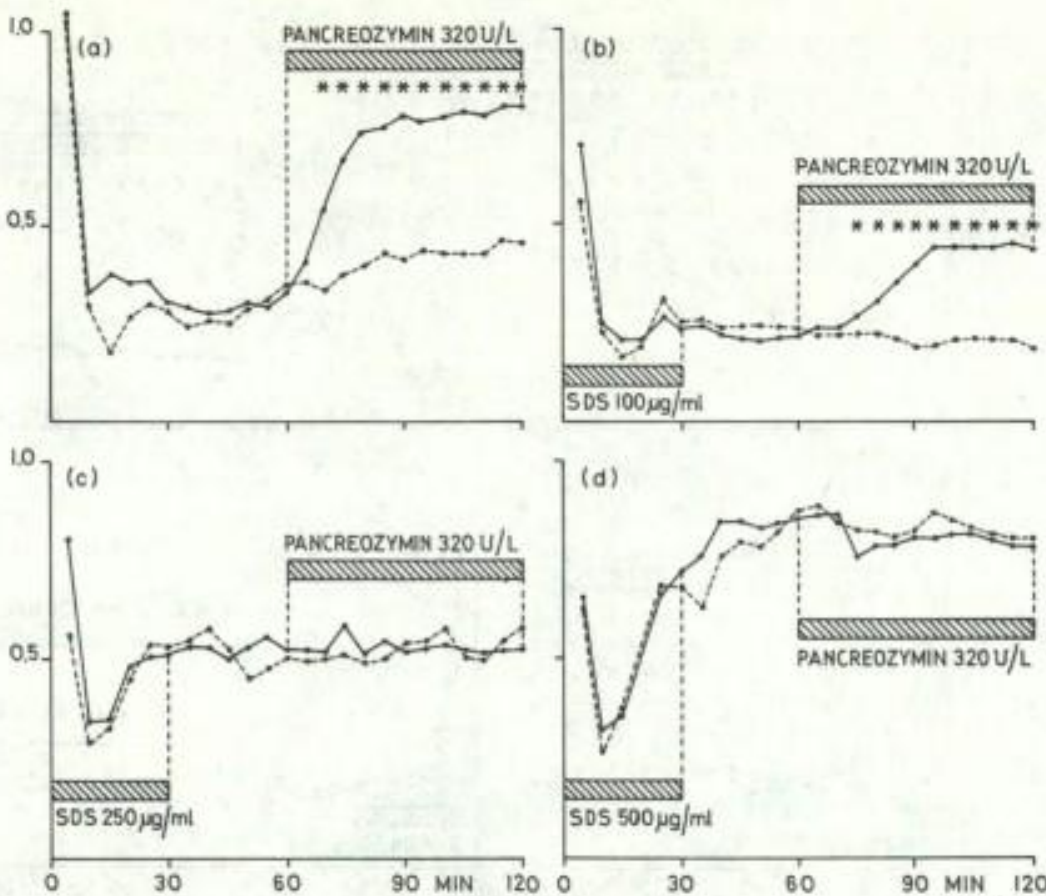

Fig. 2. Effect of sodium dodecylsulfate (SDS) pretreatment on amylase secretion in the presence (-) and in the absence (-) of pancreozymin. SDS was administered for $30 \mathrm{~min}$ in increasing concentration $(0-01-0-05 \%)$. Same representation of data as in Fig. 1. Means of three experiments.

rapidly stimulated amylase output, so that a plateau corresponding to a 2 -fold increase in basal secretion was attained within $20 \mathrm{~min}$ of hormone administration.

This stimulation decreased progressively and finally disappeared after pretreatment with increasing concentrations of the three detergents, or of trypsin.

Effects of $\mathrm{NaF}$ with or without preliminary treatment with detergents or trypsin. The introduction of $10 \mathrm{mM}$ $\mathrm{NaF}$ in the medium resulted in biphasic stimulation
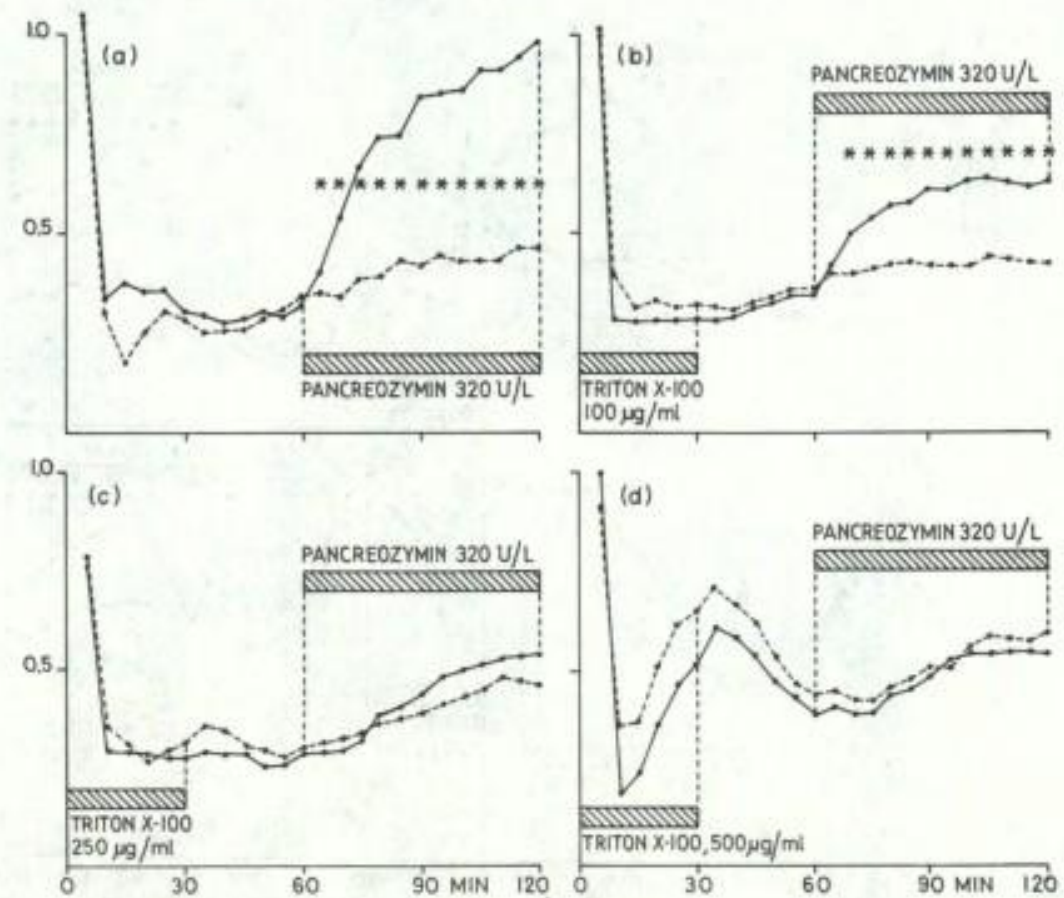

Fig. 3. Effect of Triton X-100 pretreatment on amylase secretion in the presence $(-\quad)$ and in the absence $(-)$ ) of pancreozymin. Triton X-100 was administered for $30 \mathrm{~min}$ in increasing conen $(0-01-0-05 \%)$. Same representation of data as in Fig. 1. Means of three experiments. 

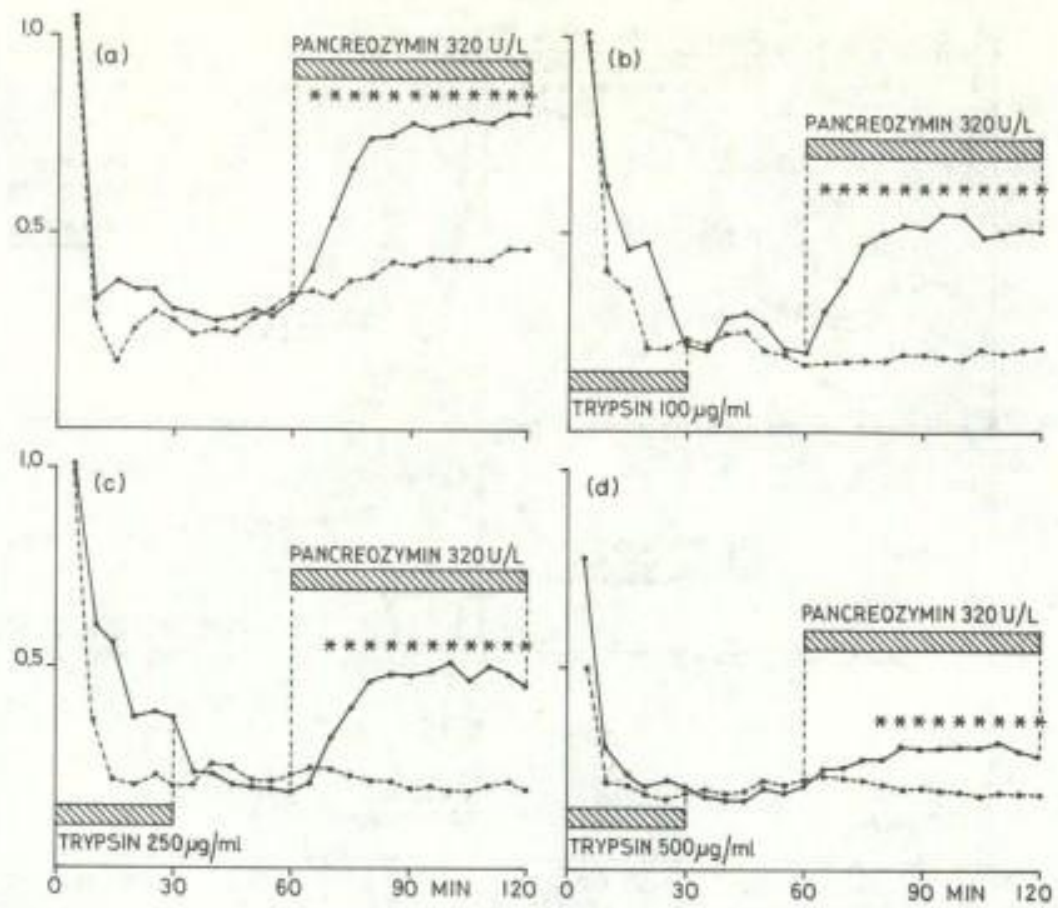

Fig. 4. Effect of bovine trypsin pretreatment on amylase secretion in the presence (- $)$ and in the absence (-) of pancreozymin. Sume methodology as in Fig 1 except for the absence of Trasylol during the 30-min exposure to increasing concentrations of trypsin (0-01-0-05\%). Means of three experiments.

of amylase secretion (Figs. 5-8). The rapid initial peak was unspecific and due only to the rise in osmolarity resulting from the addition of $\mathrm{NaF}$. The second and prolonged wave of hypersecretion was due to $\mathrm{NaF}$ itself as will be discussed later on.
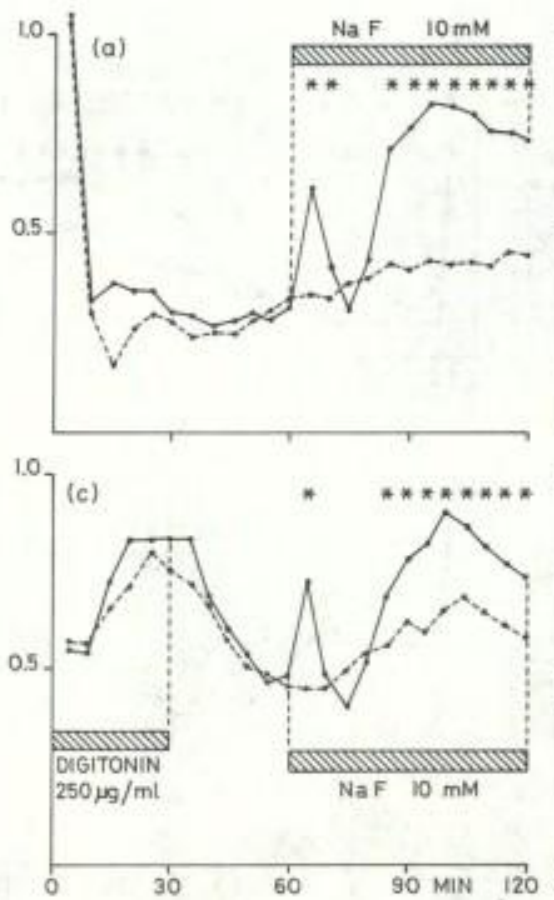

When the same experiments were repeated after exposure to detergents or to bovine trypsin, the immediate and unspecific response to the $\mathrm{NaF}$ load was not reduced, no matter how great the concentration of the agent being tested (Figs. 5-8). In fact, in the

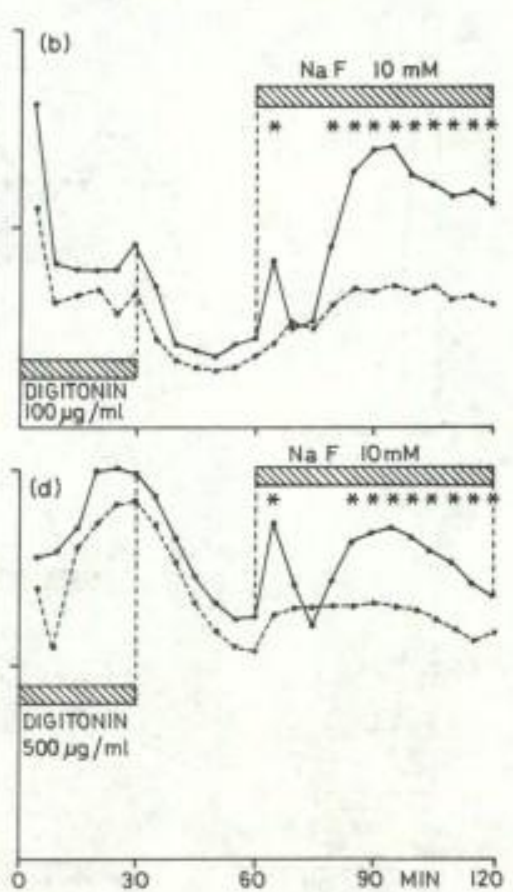

Fig. 5. Effect of digitonin pretreatment on amylase output by rat pancreatic fragments perfused in the presence (-) and in the absence $(-)$ ) of $10 \mathrm{mM}$ NaF. Same representation of data as in Fig. 1. Means of three experiments. 

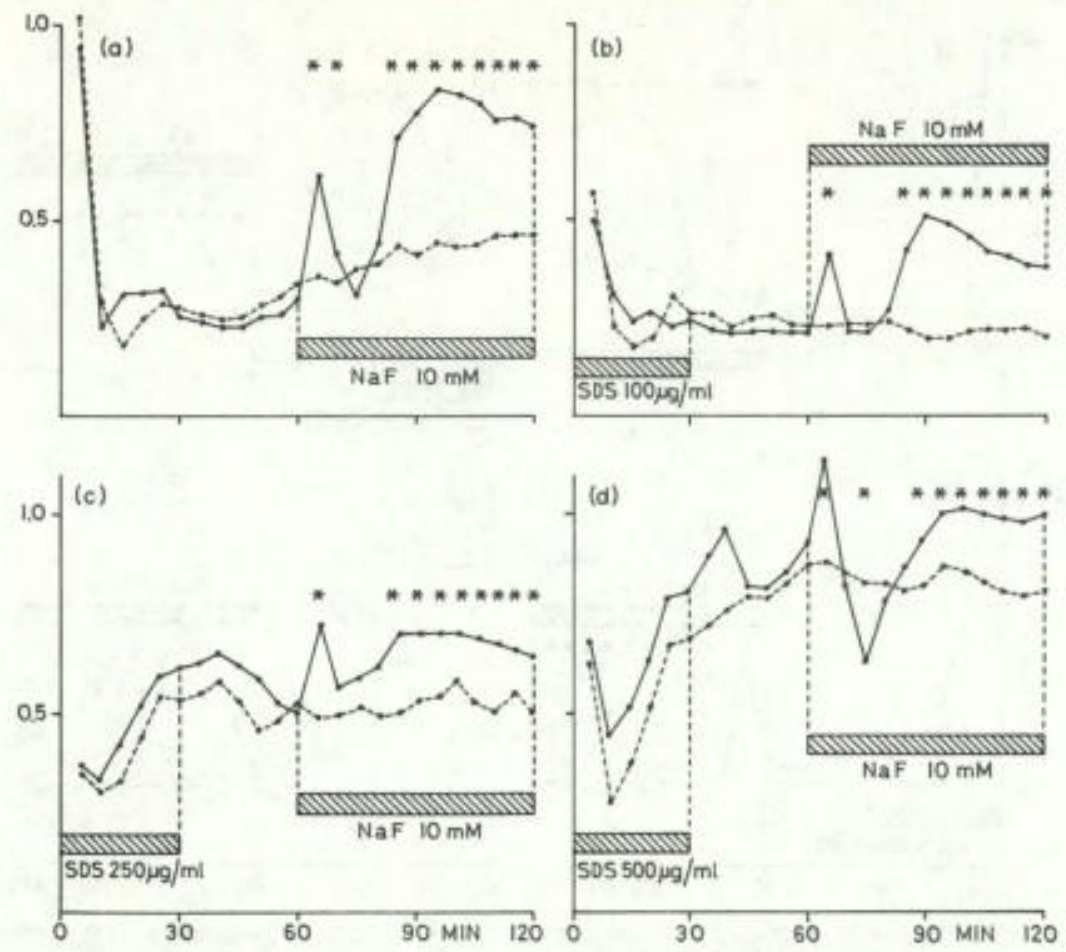

Fig. 6. Effect of sodium dodecylsulfate (SDS) pretreatment on amylase secretion in the presence (-) and in the absence $(10 \mathrm{mM} \mathrm{NaF}$. Same representation of data as in Fig 1. Means of three experiments.

presence of Triton X-100 an increase in the initial secretory peak was observed. On the other hand, the second $\mathrm{NaF}$ peak decreased after pretreatment with increasing concentrations of the three detergents and of trypsin. Although diminished, this hypersecretion persisted at concentrations of digitonin and sodium dodecylsulfate higher than those which had produced a complete insensitivity to pancreozymin (Figs. 5 and 6). In other words, sodium dodecylsulfate and digitonin concentrations which abolished the secretory
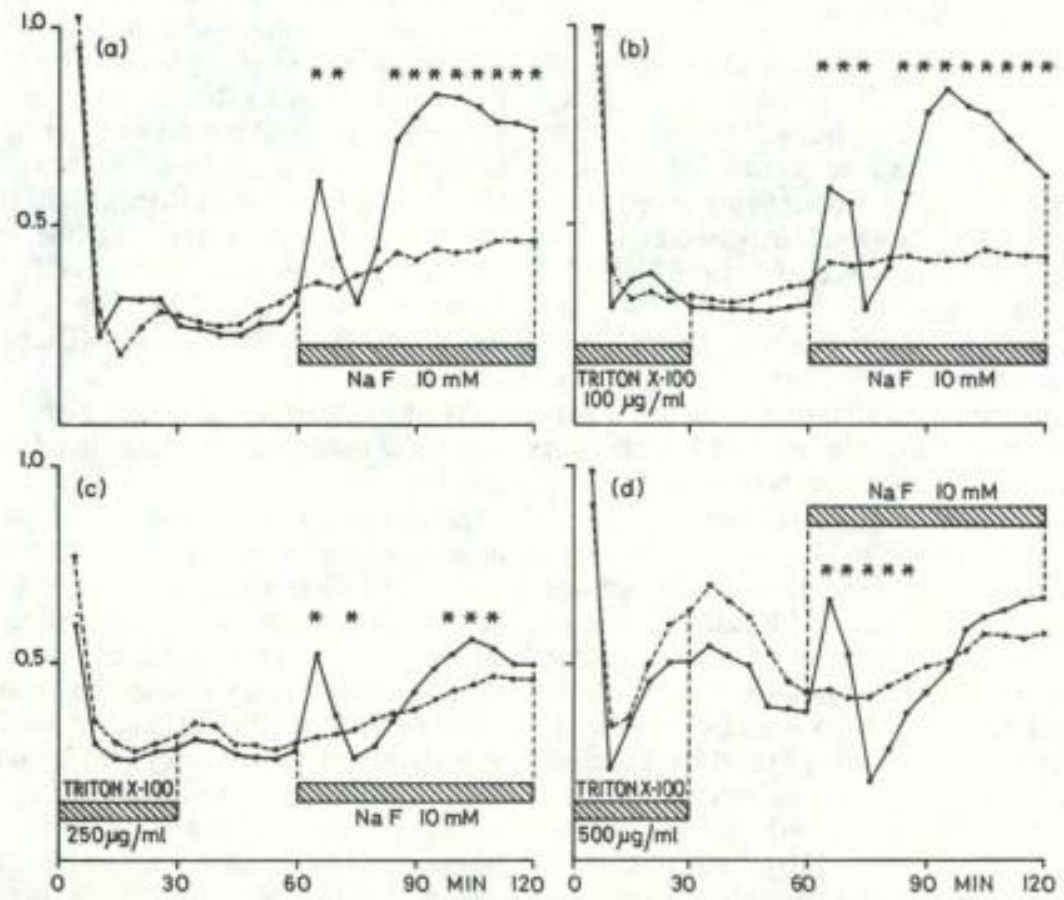

Fig. 7. Effect of Triton X-100 pretreatment on amylase secretion in the presence $(-\bullet)$ and in the absence (-) of $10 \mathrm{mM} \mathrm{NaF}$. Same representation of data as in Fig. 1. Means of three experiments. 

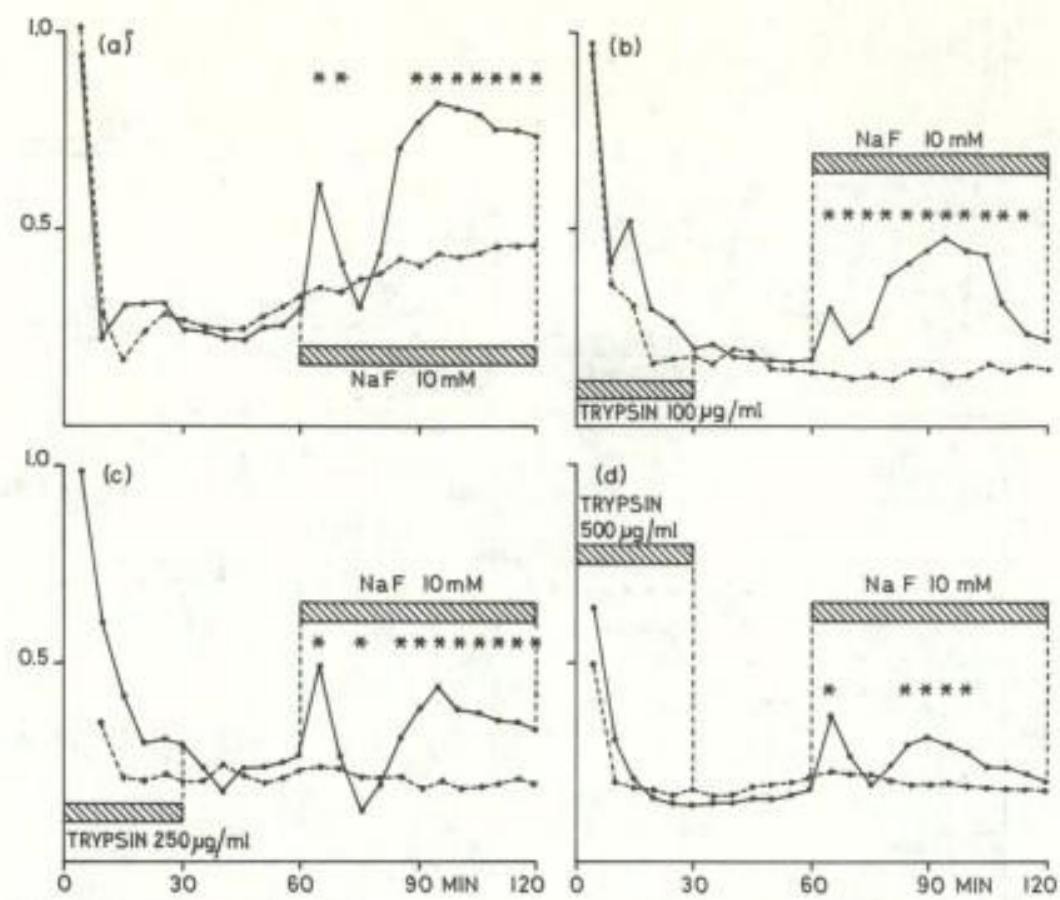

Fig. 8. Effect of bovine trypsin pretreatment on amylase secretion in the presence $(-\bullet)$ and in the absence (-) of $10 \mathrm{mM} \mathrm{NaF}$. Same methodology as in Fig. 1 except for the absence of Trasylol during the $30-\mathrm{min}$ exposure to increasing concentrations of trypsin $(0-01-0.05 \%$. Means of three experiments.

effect of pancreozymin merely inhibited the second secretory effect due to NaF. Concentrations of Triton $\mathrm{X}-100$ and trypsin able to abolish the pancreozymin effect also abolished the secretory effect of $\mathrm{NaF}$.

\section{DISCUSSION}

Nature of the immediate and secondary effects of NaF on amylase secretion. The acute secretory effect of $10 \mathrm{mM} \mathrm{NaF}$ was osmotic. Indeed, the immediate effects of $10 \mathrm{mM} \mathrm{NaCl}, \mathrm{KCl}$ or sucrose were closely analogous. Furthermore, by withdrawing an equivalent amount of $\mathrm{NaCl}$, the brief hypersecretory response occurring in the presence of $10 \mathrm{mM} \mathrm{NaF}$ disappears (data not shown).

The second and prolonged response to NaF was also obtained in the absence of hyperosmolarity, i.e. with isosmolarity maintained throughout the experimental period at the expense of $\mathrm{NaCl}$ (data not shown). This secondary effect of NaF is difficult to interpret. An inhibition of glycolysis appears not to be involved. Indeed, Bauduin [4] observed no amylase hypersecretion in response to sodium oxamate which is as efficient as NaF in blocking glycolysis in the exocrine pancreas. $\mathrm{NaF}$ is an excellent activator of a number of adenylate cyclases $[5,6]$ in acellular preparations but has never been described as stimulating this enzyme in intact cells [5] and the exocrine pancreas does not appear to be an exception to the rule $[7,8]$. On the other hand, $\mathrm{NaF}$ inhibits hepatic phosphorylase phosphatase $[9,10]$ and this compound may exert a similar effect on phospho-protein phosphatase(s) in the exocrine pancreas. The hypersecretion of pancreatic hydrolases is indeed accompanied by increased protein phosphorylation and this effect is especially important for proteins present in the membrane of zymogen granules [11]. NaF may therefore intervene in stabilizing pancreatic phosphoproteins - we observed recently that $\mathrm{NaF}$ strongly inhibits the total protein phosphatase activity present in pancreas homogenates (unpublished data).

It is also perhaps worth noting that this drug can activate a protein phosphatase present in the plasma membrane of granulocytes and platelets [12]. This suggests a possible mechanism for the activation of adenylate cyclase in these formed elements of the blood. Finally, in intact thyroid cells (but not in liver) the levels of cyclic GMP, and the incorporation of tritiated guanine into cyclic GMP increase in response to $\mathrm{NaF}$ [13]. This suggests that in at least one intact tissue, $\mathrm{NaF}$ is likely to activate a guanylate cyclase.

At any rate, it appears that $\mathrm{NaF}$ acts distal to the pancreozymin receptor when it exerts its secondary effect.

Effects of detergents and trypsin on the stimulating action exerted by pancreozymin. Our data are consistent with others describing the fragility of a series of hormone receptors and suggesting their existence as lipoproteins entities in the plasma membrane. Digitonin, sodium dodecylsulfate and Triton X-100 inhibit at first, and abolish at higher concentrations, the stimulation of adenylate cyclase by glucagon in purified hepatic plasma membrane [14]. This inhibition parallels a marked reduction in the binding of the hormone to its receptor site [15] and can be partially restored with the addition of phosphatidylserine. Similarly, the incubation of fat cell membranes in the presence of digitonin alters the response of adenylate cyclase to glucagon, ACTH, secretin and epinephrine 
[14]. Like responses are found in the case of trypsin [16].

The treatment of plasma membrane with some detergents may solubilize a membrane receptor. Cuatrecasas [17] was able to pull the insulin receptor off liver membranes with Triton X-100. Similar results were obtained by Levey [18] on myocardial adenylate cyclase.

Dissociation of the effects of digitonin and sodium dodecylsulfate on the stimulation of amylase secretion by $\mathrm{NaF}$ and pancreozymin. In our experiments with Triton X-100 and bovine trypsin, there existed a parallel between the disappearance of the stimulatory effect of pancreozymin and of the prolonged second hypersecretory effect of $\mathrm{NaF}$.

On the other hand, after pretreatment with digitonin or sodium dodecylsulfate, the proper effect of $\mathrm{NaF}$ persisted whereas the response to pancreozymin totally disappeared. These results are in accord with those of Birnbaumer et al. [14]. These authors have found that digitonin and sodium dodecylsulfate inhibit the response of liver membrane adenylate cyclase to glucagon while increasing the response to $\mathrm{NaF}$.

Taken together, our data suggest that pancreozymin and $\mathrm{NaF}$ act on two distinct loci of the plasma membrane of acinar cells and that the lipoprotein structure of this membrane was altered less extensively by digitonin (a glycoside) and sodium dodecylsulfate (a long chain anionic surfactant) than by equal weights of Triton X-100 (a nonionic detergent) and bovine trypsin.

Acknowledgements-This work was supported by grant No, 20,403 from the Fonds de la Recherche Scientifique Medicale (Belgium). We wish to express our thanks to Dr. Wald (Bayer, Brussels) for the gift of Trasylol.

\section{REFERENCES}

1. P. Robberecht and J. Christophe, Am. J. Physiol. 220. 911 (1971)

2. G. Noelting and P. Bernfeld, Helv, chim. Acta 31, 286 (1948).

3. A. Vandermeers, M. C. Vandermeers-Piret and J. Christophe, Biochimie 53, 859 (1971).

4. H. Bauduin, M. Colin and J. E. Dumont, Biochim. biophys. Acta 174, 722 (1969).

5. G. A. Robison, R. W. Butcher and E. W. Sutherland, A. Rex. Biachem. 37, 149 (1968)

6. S. L. Pohl, L. Birnbaumer and M. Rodbell, J. biol. Chem. 246, 1849 (1971).

7. M. Deschodt-Lanckman, P. Robberecht and J. Christophe, Arch. int. Physiol. Biochem. 81, 586 (1973).

8. W. J. Rutten, J. J. H. M. De Pont and S. L. Bonting. Biochim. biophys. Acta 274, 201 (1972).

9. W. D. Wosilait and E. W. Sutherland, J. biol. Chem. 218, 469 (1956).

10. J. Goris, L. Pijnenborg-Vercruysse and W. Merlevede, Biochim, biophys. Acta 268, 158 (1972).

11. M. Lambert, J. Camus and J. Christophe, Biochem. biophys. Res. Commun. 52, 935 (1973).

12. P. Layne, A. Constantopoulos, J. F, X. Judge, R. Rauner and V. A. Najjar, Biochem. biophys. Res. Commun. 53, 800 (1973).

13. K. Yamashita and J, B. Field, J, biol. Chem. 247, 7062 (1972).

14. L. Birnbaumer, S. L. Pohl and M. Rodbell, J. biol. Chem. 246, 1857 (1971).

15. S. L. Pohl, H. M. J. Krans, V. Kozyreff, L. Birnbaumer and M. Rodbell, J. biol. Chem. 246, 4447 (1971).

16. M. Rodbell, L. Birnbaumer and S. L. Pohl, J. biol. Chem. 245, 718 (1970).

17. P. Cuatrecasas, Proc. Natn. Acad. Sci. U.S.A. 69, 318 (1972).

18. G. S. Levey, Ann. N.Y. Acad. Sct. 185, 449 (1971). 